\title{
Exploring the Determinants of Intrinsic Interest among Undergraduate Accounting Students
}

\author{
Sofik Handoyo \\ Department of Accounting, Faculty of Economics and Business, Universitas Padjadjaran, Indonesia
}

\begin{tabular}{|c|c|}
\hline Article Info & ABSTRACT \\
\hline Article history: & \multirow{10}{*}{$\begin{array}{l}\text { The purpose of the study is to identify the determinants that are closely } \\
\text { associated with intrinsic interest among undergraduate accounting students. } \\
\text { Descriptive statistical analysis and correlation analysis were applied in this } \\
\text { study. The data was generated through questionnaire instruments using the } \\
\text { seven points of the Likert scale. The study involved } 136 \text { samples of } \\
\text { undergraduate accounting student at Universitas Padjadjaran. Reliability and } \\
\text { Validity tests were conducted to make sure the items of questions are valid } \\
\text { and the internal consistency are present. There are five independent variables } \\
\text { in this research, namely intrinsic interest, extrinsic interest, self-efficacy, } \\
\text { parental and peer influence, and anticipated conflict. Results indicate that } \\
\text { extrinsic interest and self-efficacy are positively and significantly associated } \\
\text { with the intrinsic interest of undergraduate accounting student. Meanwhile, } \\
\text { parental and peer influence and anticipated conflict are negatively associated } \\
\text { with the intrinsic interest of undergraduate accounting students. The } \\
\text { magnitude of correlation for anticipated conflict is significant, however, } \\
\text { parental and peer influence was found not significant. }\end{array}$} \\
\hline Received Feb 20, 2018 & \\
\hline Revised Apr 22, 2018 & \\
\hline Accepted May 06, 2018 & \\
\hline Keywords: & \\
\hline & \\
\hline Extrinsic interest & \\
\hline Intrinsic interest & \\
\hline Self-efficacy & \\
\hline Subjective norms & \\
\hline
\end{tabular}

Copyright $@ 2018$ Institute of Advanced Engineering and Science. All rights reserved.

\section{Corresponding Author:}

Sofik Handoyo,

Department of Accounting-Faculty of Economics and Business,

Universitas Padjadjaran,

Jalan Dipati Ukur 35, Bandung, Indonesia, 40132.

Email: sofik.handoyo@unpad.ac.id

\section{INTRODUCTION}

Accounting study program is one of the most popular study programs among high school students who want to continue their education at the higher education institutions. The fact of the popularity of accounting study program can be identified from the applicants of accounting study program each year both in private and state universities. In social studies, accounting study program is frequently in top position in terms of a number of applicants. The factors that make accounting study program to be one of the most favorite study programs in social science are still lack of information. Plenty of argumentations such as easiness to get a job, high-income expectation, positioned as a prestigious field of study are frequently mentioned to be the background of selecting accounting field of study as majoring. However, there is still lack of empirical evidence based on academic research findings. Therefore, there is a need to further investigate the behavior intention among accounting students in terms of their decision to choose a field of study.

Success in pursuing study in higher education is heavily depending on students perceive the subjects. If the students have a negative perception towards the subjects, the motivation of the students to conduct the study is predicted low, and it lead to a risk of failing to complete the study. On the other hand, if the students have positive perception toward the subjects, the possibility to achieve high academic achievement and to complete the study faster is high. Positive perception toward the subject refers to intrinsic interest, it is a condition where the student feel passion and excitement in performing tasks [1]. It is important 
to understand intrinsic interest among students due to its pivotal role in determining the key success of students in pursuing study at the higher education institutions. Intrinsic interest is not only contributing to student's passion to learn something but also plays an important role that determines the student's learning quality [2], [3].

Curriculum in accounting study program is normally dominated by quantitative subjects. Senior high school students who are applying to accounting study program are expected to have a good quantitative capability. In other words, to be successful in pursuing study in accounting study program, the students must be strong in mathematics. Normally, the students who are not passionate in mathematics avoid the study program that is dominated by quantitative subjects. This phenomenon leads to curiosity to understand among accounting students about their decision to choose accounting study program. Understanding determinants of intrinsic interest among accounting undergraduate student give information about the background of the students toward their decision of choosing accounting study program as majoring.

Theory of Planned Behavior (TPB), a social psychology theory, describes that behavioral intention of the individual is influenced by factors namely intrinsic interest, extrinsic interest, parental influence, anticipated conflict, and self-efficacy [4]. This study is trying to associate intrinsic interest with the rest of factors based on Theory of Planned Behavior (TPB) in a situation of choosing majoring among student of undergraduate accounting study program. By exploring motives of choosing accounting study program and its association with intrinsic interest, we can predict perceives of the students toward accounting study program based on its determinants. Since intrinsic interest is positively perceived toward accounting study program, this study is relevant to predict possibilities of the student succeed in the future based on their motives of choosing accounting study program. Furthermore, the results of the study give useful information for teachers who are giving counseling to their students in terms of choosing a field of the study at higher education institutions.

Theory of Planned Behavior (TPB) is a theory that explains the behavioral intention of the individual in making a decision. TPB is developed by Icek Ajzen and very popular among social psychology scholars. TPB describes that there are three main factors that determine intention: attitudes, subjective norms, and perceived behavioral control. An attitude in TPB is genuine individual's opinion about something that plays as a basis for decision making. Meanwhile, the subjective norm is motivation to make a certain decision because of social pressure arising from surrounding environment. Perceived behavioral control is beliefs of an individual that he or she is able to complete or finish something. An attitude itself is driven by two factors, behavioral beliefs, and evaluation of behavioral outcomes. Meanwhile, the subjective norm is driven by normative beliefs and motivation to comply.

The attitude in TPB is behavioral beliefs and behavioral outcome. Behavioral belief is perceiving positive or negative coming from an individual that influences intention. Meanwhile, evaluation of behavioral outcomes is individual intention merely based on a calculation of the outcome achieved if the intention is conducted. Behavioral beliefs in TPB is a factor that influences individual intention based on individual consideration. Behavioral beliefs in the context of the decision of choosing majoring is a perception about likeness or interesting towards the subjects that will be learned. Mean while, the behavioral outcome is based on the positive expectation that will be achieved in the future, such as job opportunity, financial rewards, and career path. Behavioral belief and evaluation of behavioral outcome in other literature are frequently called as intrinsic interest and external interest respectively [5].

Subjective norm is the second factor that is believed influencing behavioral intention of an individual based on TPB. The subjective norm in TPB is individual intention to do or not to do something due to consideration from other people and avoiding conflict with them. Other people in TRA refers to people who are very close to the individual who makes the intention. Those people are family (parent, brother, and sister, and other members of the family) and people who are considered as an important person such as peer. Choosing a majoring field of study based on advice, parents' wish or influence of close friends are common among high school students. Subjective norm is clearly the factor that influences behavioral intention of the individual that is not from internal consideration but from external consideration. It refers to the decision to do something by following parent expectation or just following someone trusted.

Perceived behavioral control is individual's motivation to do something based on the consideration that the individual believes can do (control beliefs) and has the capability to perform (perceive power). Perceived behavioral control is determined by the total set of accessible control beliefs, i.e., beliefs about the presence of factors that may facilitate or impede the performance of the behavior. Perceived behavioral control in the Theory of Planned Behavior (TPB) is identical with the concept self-efficacy proposed by Bandura. The concept of self-efficacy refers to individual perception about easy and difficult as consideration in making a decision.

TPB in social psychology study is believed as a theory that is valuable to explain various behavioral of the individual [6]. By many scholars, TPB is mostly used as a foundation for testing individual intention 
such as choosing a professional carrier, ethical behavior, and consumer behavior [7]. The TPB assumes that human behavior is based on rational consideration. It is believed that student's intention in choosing a field of study can be explained using motivation based on attitude toward behavior, subjective norm and perceived behavioral control. Understanding intercorrelation among factors in TPB is interesting to get a clear picture associated with the decision of student in selecting accounting field of study as majoring in the study. In this research, five factors mentioned in TPB analyzed with intrinsic interest as the central object of investigation.

Based on TPB, behavioral belief or intrinsic interest is a factor that influences behavioral intention of an individual based on consideration of perceived positive of the individual. Feeling happy and satisfied in pursuing something is an indication of intrinsic interest. Motivation to do something based on intrinsic interest consideration is believed can increase creativity, job satisfaction, and job performance. Intrinsic interest in the context of selecting accounting field of study as majoring is reflected in the behaviors, such as student's interest, likeness or curiosity toward accounting subjects of accounting study program. It is believed that intrinsic interest is fundamentally associated with student's decision to select accounting field of study as majoring. Accounting study program is dominated by subjects with quantitative approach. Therefore, without any intrinsic interest, it is least possibility that the student choose accounting study program as majoring.

Argumentation that intrinsic interest is fundamental in terms of the decision to choose majoring is supported by many types of research. Research finding reveals that intrinsic interest plays an important role that influences the decision of among accounting students to choose accounting profession as after graduated [8-10]. Adams, et. al who conducted a research about undergraduate students in terms of choosing their majoring found that intrinsic interest in accounting subject is a major factor that influences their decision Related to the process of learning, the students who choose accounting study program based on high intrinsic interest shows the high quality of learning

The capability of finding the solution of the complex problem and memorizing knowledge longer is determined by the student's intrinsic interest level. In terms of the motivation of choosing a field of study in higher education, intrinsic interest has been found as a fundamental factor that influences students' decision to choose study program in accounting [11]. Similarly, in terms of career choices among accounting students, intrinsic interest has also been determined as a significant predictor [12].

\section{RESEARCH METHOD}

2.1. Analysis

This research applies bivariate correlation analysis to examine whether the proposed hypotheses are accepted or rejected. Correlation analysis is the process of studying the strength of that relationship with available statistical data. Proposed hypotheses are two independent variables; therefore, bivariate correlation analysis is suitable analysis method. Coefficient correlation of Pearson Product Moment is applied in this research. The proposed hypothesis is accepted if the direction of correlation in the hypothesis is in line with the direction of correlation based on statistic calculation. SPSS software version 23 is used in this research to assist data analysis.

\subsection{Measurement, Validity, and Reliability}

Variables latent intrinsic interest, external interest, self-efficacy, parent and peer influence and anticipated conflict are measured using 7 point Likert scales. The scale 1 represents "Strongly Disagree" and the scale 7 represents "Strongly Agree". To make sure that each item of questions is valid, validity test is conducted. Validity is the extent to which a test measures what it is supposed to measure. Item of question is valid if Correlation Product Moment(r) > (r) Table. Furthermore, reliability test is also conducted to identify the consistency of the measurement. Reliability is the degree to which a test consistently measures whatever it measures. The construct of measurement is reliable if the value Cronbach's alpha $>0.7$

\subsection{Sampling Method and Data Collection}

The purposive sampling method is applied in this research. The argumentation of using purposive sampling is because the research wants to capture respondents who are newly registered as a student of accounting undergraduate program. Therefore, purposive sampling is the sampling method that is considered fit for the purpose of the study. The data are collected using questionnaire instrument and distributed directly to the students of accounting undergraduate program. The instrument of the questionnaire is sorted based on its completeness in answering the questionnaire. The questioners found incomplete is removed from the list of data. 


\subsection{Hypotheses}

TPB explains that individual attitude toward intention is affected by the evaluation of behavioral outcomes. It refers to the calculation of the benefits achieved if a certain action is conducted. Extrinsic interest in the context motivation to choose a field of study in higher education may refer to an expectation to get an easy job after graduate, high salary income, and recognition of social status. Extrinsic interest may explain the phenomenon of a number of applicants of accounting study program that is almost always in top position in social studies. Demand for graduates of accounting study program in job markets shows stable even increasing the number. Additionally, compensation for accounting profession is relatively higher compared to other social program graduates. Those extrinsic interests may influence the decision among high school students to select accounting field of study as majoring for their university education.

Studies conducted by Felton, et. al, and Ahmed, et. al reveal that extrinsic factors such as salary and job opportunity are important factors that influence the decision about choosing a field of study. More specifically, compared to non-accounting students, accounting students have been found to place more importance on extrinsic interests $[13,14]$. The reason for undergraduate accounting students choosing public accountant instead of management accountant is related extrinsic interests such as job opportunities and salary income [15]. A study by Mazni and Zamzulailai revealed that among Malaysian accounting students, they choose public accountant as a career option because of consideration such opportunity of advancement, office atmosphere, and expected future salary [16].

Income and salary are on big three positions as consideration among students who choose accountant as a career [17]. Financial factor has explanatory power to explain the reason why the students want to work as CPA [18]. Saemann and Crooker found that financial reward is the variable that plays an important role among students who choose accounting study program as majoring [19]. Based on the literature described above, the hypothesis is proposed as follows:

Hypothesis 1. Student's extrinsic interest is positively and significantly associated with student's intrinsic interest in accounting subjects

Self-efficacy in TPB is a concept adopted from social cognitive theory introduced by Bandura. It explains that desired goals attained through person's belief in their capabilities that he/she can engage in certain behaviors successfully [20]. The expected outcome can be produced successfully if the person has the conviction to execute it. An individual who has self-efficacy has tendency actively in taking action or making a decision. On the other hand, individual who has lack of self-efficacy has tendency acting as a passive person and avoiding risks. Behavioral of the individual is therefore determined by its self-efficacy, high selfefficacy increases confidence to take a risk and low self-efficacy tends to avoid risks. Self-efficacy has been identified as the determinant that influences individual behaviors such as decision making, efforts to success, perseverance, stress, and depression [21,22].

There are two studies have examined the influences of self-efficacy on student's decision to choose accountant as a professional career. Hayes and Credle found that self-efficacy is positively associated with students' decision to join the accounting profession [23]. James and Hill revealed that the low self-efficacy has been estimated as the possible cause that African-American accountants in the USA are decreasing [24]. Accounting study program is dominated by subjects that require capabilities in quantitative. Normally, study program that contains a high portion of quantitative approach avoided by those who are not interested in it. Only students who have self-efficacy or students who believe in their capabilities, choose accounting study program as majoring. Based on explanation mentioned above, proposed hypothesis is formulated as follows:

Hypothesis 2. Student's self-efficacy is positively and significantly associated with student's intrinsic interest in accounting subjects

Involvement of families and peer decision to choose majoring is common among high school students. Normally, they do not have any clear picture about higher education and career. Therefore, any information from external or another person will be valuable. In social psychology, intention and behavior of an individual can be influenced by surrounding environments such as peers, family members, relatives, and teachers. Those can act as social pressures to individual and plays role in individual's behavior. Individual's behavior determined by the social pressure in TPB is called as subjective norms [25]. Pearson and DellmanJenkins revealed that there is the influence of parent in terms of student's decision in selecting college and field of study [26]. Previously study by Silverstone and Williams found that around 26 percent of female chartered accountants in England and Wales admits that there is parent's contribution to their career choice [27]. Case in the USA, parents are an important reference to student's decision of choosing study program in accounting [28]. Theory of Planned Behavior recognizes individual decision because of the influence of surrounding environment as subjective norm construct. Significant referent groups that have been found to influence accounting students' career intentions include parents, peers, and teachers [29]. Case in Asia shows that Asian students tend to have high consideration on their parent advice regarding their study in higher education institutions. Even though the influence of parents and peers is common in deciding majoring, 
however, it created automatically perceived intrinsic interest toward the subjects among the students. If the decision to choose majoring is influenced by another person, not sourcing from student's self, the possibility of negative perception toward the subject is high among the students. Therefore, proposed hypothesis is formulated as follows:

Hypothesis 3. Parent and peer influence of the student is negatively and significantly associated with intrinsic Interest in accounting subjects

Concept Anticipated conflict in TPB explains that behavior of the individual is determined by consideration of avoiding friction with people surrounding. It refers to a respected person and usually associated with parents and families. An individual who makes a decision based on anticipated conflict consideration puts general consensus more important than individual consensus. Sacrifation own interest over general interest is the fundamental of anticipated conflict in TPB. In the context of student's decision of choosing a field of study in higher education, the background of parent and families professional job could play a significant role [30]. The students potentially avoid the field of study that is not their family or parent concern.

Career development literature has suggested that students tend to alter their future careers due to the anticipated conflict [31-34] including choosing a career with lower anticipated conflicts. Avoiding family conflict has been identified as a determinant of the individual to choose accountant as a professional career $[35,36]$ and has been associated with turnovers in accounting firms [37]. Career development literature explains that university students tend to decide their future career profession due to avoiding conflict with their family or taking the lowest risk of conflict. If the motive of choosing majoring is not based on personal interest, rather than avoiding conflict with a respected person, the students have a high possibility of negative perception towards accounting subjects. Therefore, we can propose a hypothesis as follows:

Hypothesis 4. Student's anticipated conflict is positively and significantly associated with intrinsic interest in accounting subjects

\section{RESULTS AND ANALYSIS}

\subsection{Descriptive Statistic}

The study is conducted at Universitas Padjadjaran for accounting undergraduate program. A total number of sample is 136 students, consisting of 48 male students (35\%) and 88 female students $(65 \%)$. The composition of the sample shows unbalanced between male and female. It is caused by the majority of accounting undergraduate program dominated by the female gender. The details distribution sample based on the gender is depicted in Table. 1

Table 1. Distribution of Sample by Gender

\begin{tabular}{lccc}
\hline 3 & Male & Female & Total \\
\hline Number & 48 & 88 & 136 \\
Percentage & $35 \%$ & $65 \%$ & $100 \%$ \\
\hline
\end{tabular}

Sample distribution in terms of year of study is dominated by students who are in the second year of study (46\%) and third year of study (44\%). Meanwhile, sample identified in fourth year and fifth year is only $9 \%$ and $1 \%$ respectively. The selection of the sample is suitable for the purpose of the study, which is capturing accounting undergraduate students who are at the entry level. The study is about the understanding motivation of accounting undergraduate student in selecting accounting study program as majoring in the study, therefore, choosing entry-level student is fit with the purpose of the study. The detailed distribution of sample based on the year of study is depicted in Table 2.

Table 2. Distribution of Sample by Year of Study

\begin{tabular}{lccccc}
\hline Year of study & Second Year & Third Year & Fourth Year & Fifth year & Total \\
\hline Number & 62 & 60 & 12 & 1 & 136 \\
Percentage & $46 \%$ & $44 \%$ & $9 \%$ & $1 \%$ & $100 \%$ \\
\hline
\end{tabular}

\subsection{Intrinsic Interest}

There are three item questions to measure construct variable latent intrinsic interest. Test of validity item questions indicates that all the item questions are reliable ( $r$-Value $>$ r-Table). Therefore, all of the item questions represent measurement for variable latent intrinsic interest. In terms of reliability or consistency 
measurement, the statistic result shows that there is the consistency of measurement (Cronbach's $\alpha>0.7$ ). The detail of validity and reliability test of intrinsic interest is depicted Table 3 .

Table 3. Intrinsic Interest Validity and Reliability

\begin{tabular}{ccccc}
\hline Intrinsic Interest & r-Value* & $\begin{array}{c}\text { r-Table** } \\
\mathrm{N}=40\end{array}$ & Mean & Cronbach's $\alpha$ \\
\hline Accounting subjects are interesting & 0.806 & 0.167 & 5.022 & 0.838 \\
Likeness towards accounting subjects & 0.815 & 0.167 & 4.904 & 0.838 \\
Accounting subjects are challenging & 0.652 & 0.167 & 5.845 & 0.838 \\
\hline *Pearson Correlation, **Product Moment, Sig.0.05, two-tailed & &
\end{tabular}

Analysis of item questions shows that the accounting students who are choosing accounting field of study as majoring found their intrinsic interest heavily is because the subject of accounting is challenging (Mean 5.845 of maximum 7.0). The students put a value moderately to accounting subject interesting (Mean 5.022 of maximum 7.0) and likeness toward accounting subject (Mean 4.904 of maximum 7.0). It means that intrinsic interest among accounting students toward accounting subjects heavily that they feel challenged to study accounting majoring rather than likeness toward the subject or attractive power of the subject itself. It can be interpreted that probably most students who choose accounting field of study as majoring are influenced by curiosity to study something they have never experienced before. It is supported by the facts that the number of accounting students majority are not from social study but it is from science. Accounting students who do not have experience in studying accounting in high school, because their program is science, will choose accounting study program as majoring because they feel accounting subject is challenging

\subsection{Extrinsic Interest}

Measurement of extrinsic interest uses three item questions and all the questions show validity to measure construct latent variable extrinsic interest ( $r$-Value $>r$-Table). In terms of reliability or consistency of measurement toward the construct, statistical test result shows that construct measurement is reliable (Cronbach's $\alpha>0.7$ ). The detail of validity and reliability test of extrinsic interest is depicted Table 4 .

Table 4. Extrinsic Interest-Validity and Reliability

\begin{tabular}{|c|c|c|c|c|}
\hline Extrinsic Interest & r-Value* & $\begin{array}{c}\text { r-Table** } \\
\mathrm{N}=40\end{array}$ & Mean & Cronbach's $\alpha$ \\
\hline Graduate from accounting study is given big opportunity in the job market & 0.886 & 0.167 & 5.948 & 0.903 \\
\hline The accounting profession is promising in terms of financial reward & 0.928 & 0.167 & 5.602 & 0.903 \\
\hline Accounting profession provides clear career path & 0.935 & 0.167 & 5.794 & 0.903 \\
\hline
\end{tabular}

*Pearson Correlation, **Product Moment, Sig.0.05, two-tailed

Analysis of the content of the questions indicates that by studying accounting as majoring, they get benefits from it in terms of opportunity to get a job in the job market (Mean 5.948 of maximum 7.00), financial reward (Mean 5.602 of maximum 7.00) and career path (Mean 5.794 of maximum 7.00). It implies that students of accounting program are motivated to study accounting due to the high expectation of an outcome that they get after graduating from the program. They have a motivation to study accounting to secure their future in terms of finding job, income, and career path. This finding may be explanation towards phenomena of favoritism of accounting study program among applicants who want to apply at the University for social science. Positive expectation among applicants after completing the accounting study program leads them to apply for accounting as majoring

\subsection{Self Efficacy}

There are seven item questions to measure construct variable latent self-efficacy. Test of validity item questions indicates that all of the item questions are reliable ( $r$-Value $>$ r-Table). Therefore, all of the item questions represent measurement for variable latent self-efficacy. In terms of reliability or consistency measurement, the statistic results show that there is the internal consistency of measurement (Cronbach's $\alpha$ $>0.7$ ). The detail of validity and reliability test of intrinsic interest is depicted in Table 5 . 


\begin{tabular}{|c|c|c|c|c|}
\hline Self-Efficacy & r-Value* & $\begin{array}{c}\text { r-Table** } \\
\mathrm{N}=40\end{array}$ & Mean & Cronbach' $\alpha$ \\
\hline Capability to handle the problem in the unexpected situation & 0.817 & 0.167 & 5.227 & 0.889 \\
\hline Capability to find solution of the problem & 0.873 & 0.167 & 5.110 & 0.889 \\
\hline Capability to find solution from own initiatives & 0.811 & 0.167 & 5.125 & 0.889 \\
\hline Capability to stay calm in facing a problem & 0.576 & 0.167 & 4.647 & 0.889 \\
\hline Self-confidence to achieve stated goals & 0.714 & 0.167 & 5.492 & 0.889 \\
\hline The belief that anything can be achieved with hard work & 0.843 & 0.167 & 5.757 & 0.889 \\
\hline Never give up and try hard work in facing any obstacles & 0.830 & 0.167 & 5.588 & 0.889 \\
\hline
\end{tabular}

Analysis from the questionnaire shows that the respondents as accounting undergraduate program have high value in self-efficacy. It implies that students who choose accounting field of study as majoring have personal characteristic self-confident and beliefs that they have the capability to complete the study. Accounting study program is dominated by the subjects with quantitative approach. Those who do not have sufficient quantitative capabilities face constraints to complete the study with good academic achievement. Based on items questions depicted in Table 5, the respondents indicate having a high value of self-efficacy with a mean above 5.00 of maximum 7.00, except question for the capability to stay calm in facing a problem. It can be concluded that accounting undergraduate students are characterized as individuals who have a high value of self-efficacy or self-confidence to face any challenge and problem with hard work.

\subsection{Parental and Peer Influence}

Measurement of parental and peer Influence uses three item questions and all the questions show validity to measure construct latent variable ( $r$-Value $>r$-Table). In terms of reliability or internal consistency of measurement toward the construct, statistical test result shows that construct measurement is reliable (Cronbach's $\alpha>0.7$ ). The detail of validity and reliability test of parental and peer Influence is depicted Table 6.

Table 6. Parental and Peer Influence Validity and Reliability

\begin{tabular}{lcccc}
\hline \multicolumn{1}{c}{ Parental and Peer Influence } & r-Value* & $\begin{array}{c}\text { r-Table** } \\
\text { N=40 }\end{array}$ & Mean & Cronbach's $\alpha$ \\
\hline Choosing accounting program due to parents' want & 0.812 & 0.167 & 3.022 & 0.799 \\
Choosing accounting program due to parents' advice & 0.853 & 0.167 & 3.639 & 0.799 \\
Choosing accounting program due to influence of peer & 0.478 & 0.167 & 2.772 & 0.799 \\
*Pearson Correlation, **Product Moment, Sig.0.05, two-tailed & & &
\end{tabular}

The findings from the questionnaire instrument show that majority of accounting undergraduate choosing accounting field of study as majoring is due to low influence from another person (family and peer). Even though parent's advice factor indicates quite moderate influence (Mean 3.639 of maximum 7.00), in general, influence from peer and family is low. It is consistent with the finding in intrinsic interest and selfefficacy that majority of undergraduate accounting choosing their majoring based on factor from own student consideration. Interest in accounting subject and expectation of an outcome that they are mostly influenced by student's own perception. Meanwhile, self-efficacy indicates that accounting students are individuals who are independent and self-confidence. They are not influenced by families or peer to decide their majoring but merely decision based on rational thinking and manifestation of individuals who have character high selfefficacy

\subsection{Anticipated Conflict}

There are three item questions to measure construct variable latent anticipated conflict. Test of validity item questions indicates that all of the item questions are reliable (r-Value > r-Table). Therefore, all of the item questions represent measurement for variable latent anticipated conflict. In terms of reliability or consistency measurement, the statistic results show that there is the internal consistency of measurement (Cronbach's $\alpha>0.7$ ). The detail of validity and reliability test of anticipated conflict is depicted in Table 7 . 
Table 7. Anticipated Conflict - Reliability and Validity Test

\begin{tabular}{|c|c|c|c|c|}
\hline Anticipated Conflict & r-Value* & $\begin{array}{c}\text { r-Table** } \\
\mathrm{N}=40\end{array}$ & Mean & Cronbach's $\alpha$ \\
\hline Choosing accounting majoring due to avoiding conflict with families & 0.884 & 0.167 & 2.169 & 0.881 \\
\hline Choosing accounting majoring to make the family happy & 0.944 & 0.167 & 2.720 & 0.881 \\
\hline
\end{tabular}

*Pearson Correlation, **Product Moment, Sig.0.05, two-tailed

Analysis from a questionnaire of anticipated conflict is in line with the finding of influence from parents and peer. Means of each item questions are below 3 of maximum 7. It implies that majority of accounting undergraduate students choosing majoring is due to little involvement of perceived avoiding conflict with their family. The students put more orientation toward themselves rather than thinking about avoiding confrontation with their family if their decision to choose majoring is not in line with family's expectation. This finding is consistent with findings as previously mentioned about self-intrinsic interest, external interest, self-efficacy and parental and peer influence.

\subsection{Hypothesis Testing}

Hypothesis testing is analyzed using correlation statistic procedure. Correlation analysis is conducted with bivariate correlation method with Pearson correlation coefficient and two-tailed test of significance. The result of the correlation among independent variables is presented in Table 8 . Based on the correlation matrix depicted in Table 8, we can interpret the proposed hypothesis as summarized in Table 9.

Table 8. Pearson Correlation Matrix

\begin{tabular}{|c|c|c|c|c|c|}
\hline & Intrinsic Interest & Extrinsic Interest & $\begin{array}{c}\text { Self- } \\
\text { efficacy }\end{array}$ & $\begin{array}{l}\text { Parental influence } \\
\text { and Peer }\end{array}$ & $\begin{array}{c}\text { Anticipated } \\
\text { Conflict }\end{array}$ \\
\hline Intrinsic Interest & 1 & & & & \\
\hline Extrinsic Interest & $0.379 * *$ & 1 & & & \\
\hline Self-efficacy & $0.443 * *$ & $0.485 * *$ & 1 & & \\
\hline Parental influence and Peer & -0.161 & 0.114 & 0.107 & 1 & \\
\hline Anticipated Conflict & $-0.311 * *$ & 0.006 & 0.006 & $0.690 * *$ & 1 \\
\hline
\end{tabular}

Table 9. Summary Hypothesis Testing

\begin{tabular}{|c|c|c|}
\hline Hypothesis & r-Value & Conclusion \\
\hline $\begin{array}{l}\text { H1. Student's extrinsic interest is positively and significantly associated with student's intrinsic interest in } \\
\text { accounting subject. }\end{array}$ & $0.379 * *$ & Accepted \\
\hline $\begin{array}{l}\text { H2. Student's self-efficacy is positively and significantly associated with student's intrinsic interest in } \\
\text { accounting subject. }\end{array}$ & $0.443 * *$ & Accepted \\
\hline $\begin{array}{l}\text { H3. Parental and peer influence is negatively and significantly associated with student's intrinsic interest in } \\
\text { accounting subject. }\end{array}$ & -0.161 & Rejected \\
\hline $\begin{array}{l}\text { H4. Anticipated conflict is negatively and significantly associated with student's intrinsic interest in } \\
\text { accounting subject }\end{array}$ & $-0.311 * *$ & Accepted \\
\hline
\end{tabular}

The summary of hypothesis testing shows that only hypothesis three is not accepted. The rejection is because the magnitude of significance is not as predicted. It means that there is slightly influence from parent and peer that plays a role in terms of determining majoring among students of accounting undergraduate program. However, in terms of the direction of prediction, the hypothesis is accepted. Therefore, we can conclude that extrinsic interest and self-efficacy among undergraduate accounting students are positively significant associated with the intrinsic interest of the students in accounting subject. On the other hand, the decision to choose accounting majoring due to influence from parent and peer and anticipated conflict is negatively associated with interest intrinsic. It means that the students of accounting program find that accounting subjects are not interesting and not challenging if their decision to choose accounting majoring due to aspects influence from parent and peer and effort to avoid conflict with families

\section{CONCLUSION}

First, intrinsic interest among accounting students towards accounting subject is closely associated with extrinsic interest. Positive expectation toward an outcome that will be obtained in the future after they 
graduate from accounting study program leads to perceiving interested, likeness and challenge to study accounting subjects. Students behave positively toward the process of education (feeling interesting, likeness and challenging) because they know that it will benefit them if they are conducted properly. Even though there is a positive and significant association between intrinsic interest and extrinsic interest, there is still lack of understanding whether those factors are causal. Therefore, in the future, there is a need to study the further causal relationship between intrinsic interest and extrinsic interest.

Second, student's self-efficacy of the accounting student is positively and significantly associated with student's intrinsic interest. The finding has two implication of interesting information. The first one, the finding is kind of revealing personal characteristic among undergraduate accounting students. The result indicates that most undergraduate accounting students have a high value of self-efficacy. The high value of self-efficacy means that individual is characterized as a person who has the confidence in their capabilities in doing something or facing a problem. Second, one, the finding reveals that decision of choosing majoring is associated with the personal character of the individual. An individual who chooses accounting study program as majoring categorizes it as difficult and challenging, and most of them have a high value of self-efficacy.

Third, the influence of parents and peer is negatively associated with intrinsic interest. The finding indicates that if the decision to choose majoring of study based on other person influence, it cost perceived interest toward the subjects. Because intrinsic interest is fundamental in the learning process, therefore, the students should not always follow parents or peer advice. The parents must give a freedom to their children in terms of selecting a field of study in a higher education institution. The absence of student's intrinsic interest has the possibility to demotivation in the study process, even risk of dropping out from the university.

Fourth, anticipated conflict is negatively and significantly associated with student's self-interest. It implies that for students who select their field of study due to avoiding conflict with their parents and family, the possibility of having a risk in the learning process is high. Risks such as demotivation of the study, poor academic achievement and the worst, dropping out are potentially occurring. Therefore, in terms of choosing majoring, the students should not sacrifice their own interest in order to make parents or families happy but just follow their interest.

\section{REFERENCES}

[1] Ahmad, Z., Ismail, H., and Anantharaman, R.N. "To be or not to be: an investigation of accounting students' career intentions". Education and Training Journal. 2015, Vol. 57 No. 3, pp. 360-376.

[2] Entwistle, J. and Ramsden, P. "Understanding Student Learning", Croom Helm, London, 1983.

[3] Jackling, B. and Calero, C. "Influences on undergraduate students' intentions to become qualified accountants: evidence from Australia", Accounting Education: An International Journal, 2006, Vol. 15 No. 4, pp. 419-38.

[4] Ajzen, Icek. "The theory of planned behavior". Organizational Behavior and Human Decision Processes. 1991, 50(2): 179-21.

[5] Law, P., and Yuen, D. A. "multilevel study of students' motivations of studying accounting Implications for employers". Education and Training Journal. 2012, Vol. 54 No. 1, pp. 50-64.

[6] Sable, M., Schwartz, L., Kelly, P., Lisbon, E. and Hall, M. "Using the theory of reasoned action to explain physician intention to prescribe emergency contraception", Perspectives on Sexual and Reproductive Health, 2006, Vol. 38 No. 1, pp. 20-7.

[7] Cohen, J. and Hanno, D. "An analysis of underlying constructs affecting the choice of accounting as a major", Issues in Accounting Education, 1993, Vol. 8 No. 2, pp. 219-38.

[8] Linden, Y. "An investigation into students' motivations for selecting accounting as a career", Working Paper No. 58, Massey University, Wellington, 1987.

[9] Adams, S., Pryor, J. and Adams, L. "Attraction and retention of high aptitude students in accounting", Issues in Accounting Education, 1994, Vol. 9 No. 1, pp. 45-58.

[10] Felton, S., Buhr, N. and Northey, M. "Factors influencing the business student's choice of a career in chartered accountancy", Issues in Accounting Education, 1994, Vol. 9 No. 1, pp. 131-4.

[11] Jackling, B. and Keneley, M. "Influences on the supply of accounting graduates in Australia", Accounting and Finance, 2009, Vol. 49 No. 1, pp. 141-5.

[12] Sugahara, S. and Boland, G. "The accounting profession as a career choice for tertiary business students in Japan: a factor analysis", Accounting Education: An International Journal, 2009., Vol. 18 No. 3, pp. 255-272

[13] Tan, L. and Laswad, F. "Students' beliefs, attitudes and intentions to major in accounting", Accounting Education: An International Journal, 2006, Vol. 15 No. 2, pp. 167-87.

[14] Byrne, S. and Pierce, B. "Towards a more comprehensive understanding of the roles of management accountants", European Accounting Review, 2007, Vol. 16 No. 3, pp. 469-498.

[15] Hutaibat, K.A. "Interest in the management accounting profession: accounting students' perceptions in Jordanian universities", Asian Social Science, 2012, Vol. 8 No. 3, pp. 303-316. 
[16] Mazni, A. and Zamzulailai, Z. "Desired attributes of public accounting firms from accounting students' perceptions: the case of University of Malaya and International Islamic University of Malaysia”, Journal of Financial Reporting and Accounting, 2006, Vol. 4 No. 1, pp. 25-37.

[17] Haswell, S. and Holmes, S. “Accounting graduate employment choice”, 1988, ICA Journal, Vol. 53 No. 2, pp. 63 7.

[18] Horowitz, K. and Riley, T. "How do accounting students see us?", Accountancy, 1990, Vol. 106 No. 1165, pp. 757.

[19] Saemann, G. and Crooker, K. "Student perceptions of the profession and its effect on decisions to major in accounting", Journal of Accounting Education, 1999, Vol. 17 No. 1, pp. 1-22.

[20] Bandura, A. "Social Foundations of Thought and Action: A Social Cognitive Theory", Prentice Hall, Engelwood Cliffs, NJ, 1986.

[21] Schunk, D.H. "Self-efficacy and academic motivation", Educational Psychologist, 1991, Vol. 26 No.4, pp. 207-23.

[22] Petrovich, A. "Using self-efficacy theory in social work teaching", Journal of Social Work Education, 2004., Vol. 40 No. 3, pp. 429-445

[23] Hayes, Z.A. and Credle, S.H. "An application of social cognitive career theory: exploring factors influencing the decision to select public accounting as a career choice", International Journal of Business Research, 2008, Vol. 8 No. 5, pp. 53-63.

[24] James, K.L. and Hill, C. "Race and the development of career interest in accounting", Journal of Accounting Education, 2009, Vol. 27 No. 4, pp. 210-222.

[25] Ahmed, K., Alam, K. and Alam, M. "An empirical study of factors affecting accounting students' career choice in New Zealand”, Accounting Education: An International Journal, 1997, Vol. 6 No. 4, pp. 325-35.

[26] Pearson, C. and Dellman-Jenkins, M. "Parental influence on a student's selection of a college major", College Student Journal, 1997, Vol. 31 No. 3, pp. 301-14.

[27] Silverstone, R. and Williams, A. "Recruitment, training, employment and careers of women chartered accountants in England and Wales", Accounting and Business Research, 1979, Vol. 9 No. 33, pp. 105-21.

[28] Allen, C. "Business students' perception of the image of accounting", Managerial Auditing Journal, 2004, Vol. 19 No. 2, pp. 235-58.

[29] Auyeung, P. and Sands, J. "Factors influencing accounting students' career choice: a crosscultural validation study", Accounting Education, 1997, Vol. 6 No. 1, pp. 13-23.

[30] Weer, C.H., Greenhaus, J.H., Colakuglu, N. and Foley, S. "The role of maternal employment, role-altering strategies, and gender in college students' expectations of work-family conflict", Sex Roles, 2006, Vol. 55 Nos 7/8, pp. 535-544.

[31] Livingston, M.M., Burley, K. and Springer, T.P. "The importance of being feminine: gender, sex role, occupational and marital role commitment, and their relationship to anticipated work-family conflict", Journal of Social Behavior and Personality, 1996, Vol. 11 No. 5, pp. 179-192.

[32] Conlon, A.L. "Anticipated work-family conflict and the lifestyle expectations of female and male undergraduate and graduate students", PhD, University of Minnesota, Minneapolis, MN, 2002.

[33] Markle, G. "Work and Family Conflict Law: Expectations and Planning Among Female College Students", University of North Texas, Denton, TX, 2004.

[34] Cinamon, R.G. "Anticipated work-family conflict: effects of role salience and self-efficacy", British Journal of Guidance and Counselling, 2010, Vol. 38.

[35] Elloy, D.F. and Smith, C.R. "Patterns of stress, work-family conflict, role conflict, role ambiguity and overload among dual-career and single-career couples: an Australian study”, Cross Cultural Management, 2003, Vol. 10 No. 1, pp. 55-6.

[36] Aizzat, M.N. and Khor, L.H. "The influence of support at work and home on work-family conflict: does gender make a difference?", Research and Practice in Human Resource Management, 2008, Vol. 16 No. 1, pp. 18-30.

[37] Pasewark, W.R. and Viator, R.E. "Sources of work-family conflict in the accounting profession", Behavioral Research in Accounting, 2006, Vol. 18 No. 1, pp. 147-165. 